\title{
Expression study of an Amino Acid Permease-like gene in Phaseolus vulgaris $\mathrm{L}$.
}

\author{
Nisha Patwa ${ }^{1,2}$, Brototi Chakraborty ${ }^{1} \&$ Jolly Basak $^{1^{*}}$ \\ ${ }^{1}$ Laboratory of Genomics of Plant Stress Biology, Department of Biotechnology, Visva Bharati, Santiniketan 731235 , India. \\ ${ }^{2}$ Present address: USDA-ARS, Horticultural Insects Research Lab, Application Technology Research Unit, Wooster, OH 44691, USA. \\ *Email: jolly.basak@visva-bharati.ac.in
}

\section{ARTICLE HISTORY}

Received: 23 December 2019

Accepted: 11 March 2020

Published: 03 May 2020

\section{KEYWORDS}

Alanine; Amino acid permease-like gene; Glycine; Proline; P. vulgaris.

\section{ABBREVIATION}

AAP, amino acid permease; RTqPCR, real time quantitative polymerase chain reaction; IDE, insulin degrading enzyme

\section{ABSTRACT}

Amino acid permease-like (AAP-like) gene plays a critical role in absorbing amino acids through roots in plants. A number of studies have been done on amino acids uptake in plants but till date there is no report about the expression of $A A P$ gene in Phaseolus under field allied condition. The aim of this study is to measure the expression of $A A P$ like gene on alanine, glycine and proline amino acid uptake capacity in Phaseolus vulgaris at field relevant concentrations. Amongst three amino acids, a drastic significant increase of 63.15 fold in expression of $A A P$-like gene is observed in $50 \mu \mathrm{M}$ alanine at $2 \mathrm{hr}$. At $50 \mu \mathrm{M}$ of proline and $25 \mu \mathrm{M}$ of alanine, AAP-like gene expression also shows high expression of 43.71 fold at $2 \mathrm{hr}$ and 42.50 fold at $1 \mathrm{hr}$ respectively. This study elucidated the dose dependent relationship of glycine, alanine and proline with the expression of $A A P$-like gene in amino acid transport in natural conditions in roots of $P$. vulgaris. Additionally, this research is also useful in identification of plants needing less surplus nitrogen additions and helpful in optimizing fertilizers by tailoring $A A P$ gene expression to match plant uptake capacities in agriculture.

\section{Introduction}

Plant growth and development are dependent on the attainment and distribution of nitrogenous compounds throughout the plant body. Application of nitrogen fertilizers seems to be the only solution despite of being costly and non-ecofriendly, making this an important issue. Several compounds essential to plant development that includes nucleotides, hormones, chlorophyll and secondary metabolites are synthesized from amino acids (1). Amino acids are also the building block elements for enzymes and proteins that make the skeleton and give fuel through metabolism to the plant. Plants absorb amino acids right from the soil in the form of nitrate and ammonium and thereby assimilate them to amino acids $(2,3)$. Most of the amino acids are synthesized in plastids, cytosol, mitochondria and peroxisomes of roots and leaves and available immediately to metabolic processes. Compartmentalization and proper channelization of the amino acids throughout plant body are performed by several transporters present in the membrane (4-6).

A number of transporters are already well-known and has been grouped into different families. Amino acid permease1 (AAP1/NAT2) was identified first in plant a long ago in Arabidopsis (7-9). Near about 6500 transmembrane proteins were identified in Arabidopsis using bioinformatic tools and programming (10). Amino acid transporters are mainly belonging to amino acid permease (AAP), lysine/histidine-type transporter (LHT), proline/compatible solute transporter (ProT), aromatic-neutral amino acid transporter (ANT1), $\gamma$-aminobutyric acid transporter (GAT) and cationic amino acid transporter (CAT) families. Transporters generally differ in substrate selectivity and affinity when analyzed in yeast or Xenopus oocytes, and in tissue or cellular localization. LHT1, AAP1, AAP5, ProT2 and CAT6 transporters are involved in amino acid uptake into root cells whereas LHT, AAP8, AAP1, AAP6 and AAP2 imports amino acids into mesophyll

(c) Patwa et al. (2020). This is an open-access article distributed under the terms of the Creative Commons Attribution License, which permits unrestricted use, distribution and reproduction in any medium, provided the original author and source are credited (https://creativecommons.org/licenses/by/4.0/)

To cite this article: Patwa N, Chakraborty B, Basak J. Expression study of an Amino Acid Permease-like gene in Phaseolus vulgaris L. Plant Science Today. 2020;7(2):251256. https://doi.org/10.14719/pst.2020.7.2.712 
cells, endosperm, embryo, xylem parenchyma and transport phloem respectively. Cellular influx of glutamine and histidine, and uptake of aspartate and glutamate is performed by SIAR1 while glutamate/ malate exchange across chloroplast membrane is done by DT2.1 transporter. Yet, studies have been restricted to the physiological role that includes absorbance through root, water conducting system, mesophyll cells of leaves and seeds $(6,9,11,12)$.

Phaseolus vulgaris is well-known for high nutritive value and also for increasing soil fertility $(13,14)$ but very limited study has been conducted to characterize $A A P$ gene in Phaseolus (15). In this present study, we have amplified an amino acid permease-like gene (AAP-like) (NCBI accession number MH704902) from Phaseolus vulgaris L 'Seville' and analyze its expression pattern at different concentration of amino acids, glycine, alanine and proline under different incubation period at transcriptome level using RT-qPCR.

\section{Materials and Methods}

\section{Plant material and growth condition}

Seeds were surface sterilized using $\mathrm{HgCl}_{2}(0.1 \%)$ and sown on sterile vertical agar plates comprising nitrogen free Murashige and Skoog (MS) medium (16), $3 \mathrm{mM} \mathrm{NO}_{3}{ }^{-}, 1 \%(\mathrm{w} / \mathrm{v})$ agar and $0.5 \%(\mathrm{w} / \mathrm{v})$ sucrose and set to $\mathrm{pH} 5.8$ by $7.7 \mathrm{mM}$ MES. After seed germination, they were incubated in the growth chamber maintaining $16 / 8$ photoperiod at $24 \pm 2{ }^{\circ} \mathrm{C}$ temperature and $78 \%$ humidity. All plants were allowed to grow for seven days.

\section{Amino acid uptake}

Seven days old seedlings were removed from the agar plate and the root of the seedlings were blotted gently with tissue paper and then directly immersed into three aliquots of $0.5 \mathrm{mM} \mathrm{CaCl} 2$ to preserve membrane integrity. The solution in excess was blotted with tissue paper after dipping third time and right away the roots of intact plants were allowed to submerge in $25 \mathrm{ml}$ of a solution of glycine, alanine and proline at a $25 \mu \mathrm{M}$ and $50 \mu \mathrm{M}$ concentration separately for $2 \mathrm{hr}$ in $50 \mathrm{ml}$ vials. The roots of untreated plants submerged with water for $2 \mathrm{hr}$ were treated as control.

\section{RNA isolation and cDNA synthesis}

Total RNA was extracted from $~ 800 \mathrm{mg}$ of roots by Total RNA isolation kit (Macherey-Nagel) following manufacturer instruction at $30 \mathrm{~min}, 1 \mathrm{hr}$ and $2 \mathrm{hr}$ from the time of submerging in amino acid solution. Integrity was checked on $1 \%$ formaldehyde agarose gel and purity were checked in Nanodrop spectrophotometer (JENWAY). First strand cDNA synthesis was performed following the instructions directed in Revert Aid First Strand cDNA Synthesis Kit (Thermo Scientific).

\section{Primer designing}

Using ExPASy tool (17), the AAP-like gene sequence was translated to amino acid sequence. RT-qPCR primers were designed using PRIMER3 (18) from the long stretch of open reading frame obtained from the translation of the amino acid sequence. The primers for Insulin degrading enzyme (IDE) was as per standard (19).

\begin{tabular}{ccc}
\hline Gene & Forward primer & Reverse primer \\
\hline Amino acid & GCTTCTACAACCCATAC CACTGTCTGGGAATCT \\
permease-like gene & T & AC \\
\hline Insulin degrading & GCAACCAACCTTTCATC AGAAATGCCTCAACCC \\
enzyme & AGC & TTTG \\
\hline
\end{tabular}

\section{Quantification of AAP gene by RT-qPCR}

RT-qPCR reactions were standardized with IDE as an internal control (19) using Bio-Rad iQ SYBR Green Supermix in a Bio-Rad CFX96 Real-Time PCR system. Standard curve was done with five different concentrations of cDNA in triplicates with a twofold dilution. cDNA of $100 \mathrm{ng}$ concentration was found to give least $C_{T}$ value. The reaction mixture contains $1 X$ SYBR Green Supermix, $3.2 \mu \mathrm{M}$ of each gene specific forward and reverse primers and $100 \mathrm{ng}$ of cDNA. It was then incubated at $95{ }^{\circ} \mathrm{C}$ for $2 \mathrm{~min}$ for initial denaturation which was then followed by 40 cycles of denaturation at $95{ }^{\circ} \mathrm{C}$ for $10 \mathrm{~s}$ and annealing at $60^{\circ} \mathrm{C}$ for $20 \mathrm{~s}$. Each amplicon specificity was checked on analyzing melt curve. Each reaction was performed in triplicate and the occurrence of a single peak in melt curve, specify the specificity of the amplicon being tested. Expression pattern of AAP-like gene at different concentrations of three amino acids namely alanine, glycine and proline at different incubation time, $30 \mathrm{~min}, 1 \mathrm{hr}$ and $2 \mathrm{hr}$, was quantitated taking IDE as normalizer.

\section{Statistical analysis}

The data obtained are presented as means \pm SD . Analysis of variance (ANOVA) was done using SAS software 9.4 Copyright 2002-2012 by SAS institute Inc. to analyze the data considering each variable at particular treatment and incubation time at the 5\% level of significance.

\section{Results}

\section{Total RNA isolation and cDNA synthesis}

Total RNA was isolated and visualized on $1 \%$ formaldehyde agarose gel. Distinct bands of $28 \mathrm{~S}$ and $18 \mathrm{~S}$ rRNA were found that confirmed its integrity. The purity was checked in Nanodrop Spectrophotometer (JENWAY). The ratio of 260/280 of total RNA was found 2.0 and $260 / 230$ between 2-2.2. A smear of cDNA was found on $2 \%$ agarose gel.

\section{Relative quantification of AAP gene}

Relative quantification study was performed by RTqPCR. Specificity of the designed primers was set by analyzing melt curve. RT-qPCR was done for AAP-like gene and expressions were analyzed using IDE as a normalizer. The relative quantity of AAP-like gene was expressed in percentage and was carried out using the formula $2^{-\Delta C \mathrm{~T}}$ at $25 \mu \mathrm{M}$ and $50 \mu \mathrm{M}$ of glycine, alanine, proline and in control (20) (Fig. 1-4). For this study, three incubation time points, i.e., $30 \mathrm{~min}, 1 \mathrm{hr}$ and $2 \mathrm{hr}$ were taken to check expression level of $A A P$ like gene in presence of three amino acids glycine, 
alanine and proline separately. At $25 \mu \mathrm{M}$ and $50 \mu \mathrm{M}$ of glycine, proline and alanine, there is significant increase $(\mathrm{p} \leq 0.05)$ in $A A P$-like gene expression with the progression of time till $2 \mathrm{hr}$, except at $25 \mu \mathrm{M}$ of alanine where a gradual decrease of expression has been noticed. The highest $A A P$-like gene expression of 63.15 fold was found at $50 \mu \mathrm{M}$ of alanine and high expression of 43.71 fold was found at $25 \mu \mathrm{M}$ of proline at $2 \mathrm{hr}$. Additionally, the $A A P$-like gene expression was high in presence of $50 \mu \mathrm{M}$ of glycine and alanine at $2 \mathrm{hr}$ than at $25 \mu \mathrm{M}$ concentration except in presence of proline where the AAP-like gene expression was high at $25 \mu \mathrm{M}$ than at $50 \mu \mathrm{M}$ (Fig. 1). The AAP-like gene expression was 1.86 fold and 1.65 fold low at $25 \mu \mathrm{M}$ and $50 \mu \mathrm{M}$ of glycine at 2 hr respectively than in control (Fig. 2A, 2B). While on comparing the expression of AAP-like gene, there was no significant difference between $25 \mu \mathrm{M}$ and $50 \mu \mathrm{M}$ of glycine $(\mathrm{p} \leq 0.05)$ at $2 \mathrm{hr}$ (Fig. $2 \mathrm{C})$. In the presence of alanine, the expression of AAP-like gene was 4.28 fold low at $25 \mu \mathrm{M}$ and 3.84 fold high at $50 \mu \mathrm{M}$ at $2 \mathrm{hr}$ than in control (Fig. 3A, 3B) but showing highest expression of $A A P$-like gene at $1 \mathrm{hr}$ and $2 \mathrm{hr}$ at both concentrations (Fig. $3 \mathrm{C}$ ). The AAP-like gene expression was different in presence of proline from both glycine and alanine. The AAP-like gene expression was 2.66 fold high at $25 \mu \mathrm{M}$ and 2.89 fold low at $50 \mu \mathrm{M}$ of proline at $2 \mathrm{hr}$ than in control (Fig. $4 \mathrm{~A}, 4 \mathrm{~B})$ whereas the expression of $A A P$-like gene was found to be highest at $25 \mu \mathrm{M}$ at $1 \mathrm{hr}$ and $2 \mathrm{hr}$ (Fig. $4 \mathrm{C}$ ).

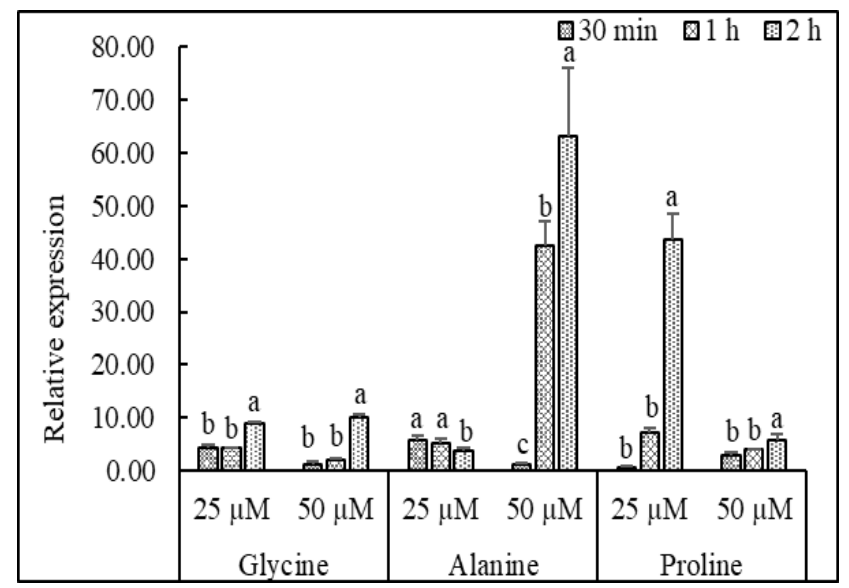

Fig. 1. Relative quantification of $A A P$-like gene after glycine, alanine and proline addition at $30 \mathrm{~min}, 1 \mathrm{hr}$ and $2 \mathrm{hr}$ in $25 \mu \mathrm{M}$ and $50 \mu \mathrm{M}$ concentration of each separately using IDE as internal control. Each column is the average of the three independent measure \pm SD. Small alphabets notation on each error bars indicated significant differences and same alphabet notation indicated no significant differences at the $5 \%$ level of significance in between incubation time of a particular treatment. AAP-like- amino acid permease-like gene; IDE- Insulin degrading enzyme.

\section{Discussion}

A different variety of organic nitrogenous compounds including amino acids may be present in agricultural land. Amino acids amount to an important nitrogen supply to plants. The amino acids in the soil in general vary from 0.1 to $60 \mu \mathrm{M}$ that make sum total of soluble nitrogen up to $10-40 \%$ (11, 21, 22). Different kinds of ecosystem have different amino acid concentration in the soil based on their structure. In an alpine region the free amino acids

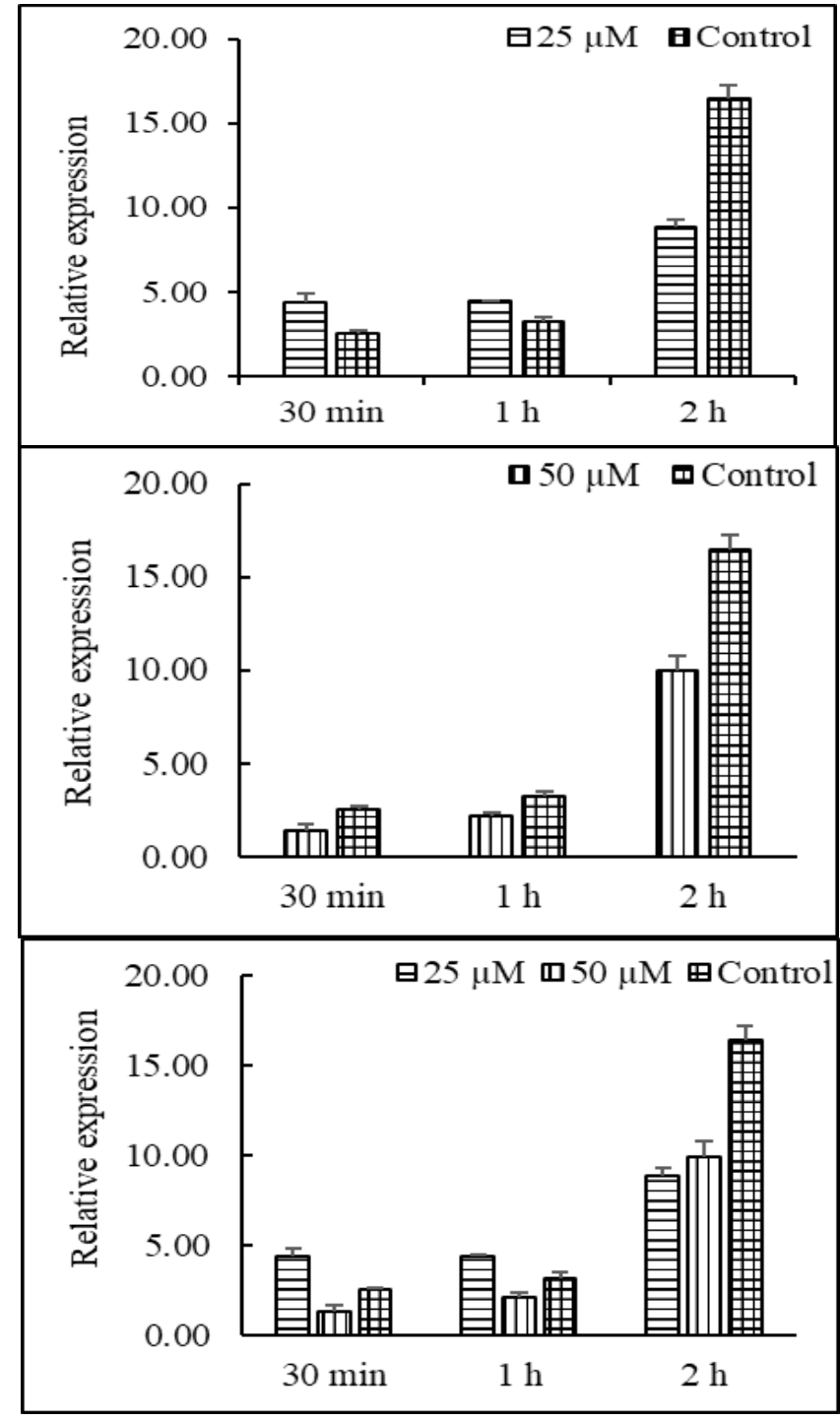

Fig. 2. Relative quantification of AAP-like gene after Glycine addition. A: $25 \mu \mathrm{M}$; B: $50 \mu \mathrm{M}$; C: Comparison between $25 \mu \mathrm{M}, 50 \mu \mathrm{M}$ and control using IDE as internal control. Each column is the average of the three independent measure \pm SD. Small alphabets notation on each error bars indicated significant differences and same alphabet notation indicated no significant differences at the $5 \%$ level of significance in between treatment and control of a particular incubation time. AAP-like- amino acid permease-like gene; IDE- Insulin degrading enzyme.

are present in range of 13-158 $\mu \mathrm{M}(23)$ and in boreal forests it is $57-73 \mu \mathrm{M}$ (24). In grasslands overall soil amino acid varies between 20-60 $\mu \mathrm{M}$ whereas individual amino acids are in the range of $0.3-10 \mu \mathrm{M}$ (21). Despite of the occurrence of very low micro molar concentrations of amino acid in soil, majority of the studies have been done at significantly high concentrations $(23,25-27)$. Very limited studies have been reported close to $0.1-10 \mu \mathrm{M}$ amino acid concentrations present in the soil (28-30).

Amino acids are the important fraction of nitrogen being absorbed by plants in terrestrial ecosystems, particularly in low nitrogen concentration (31-34). There are many amino acid transporters reported that uptake amino acid directly from soil in plants (35). Three amino acid transporters namely AAP1, AAP5 and LHT1 already have been reported playing a major role in amino acid absorption from Arabidopsis roots (12). 


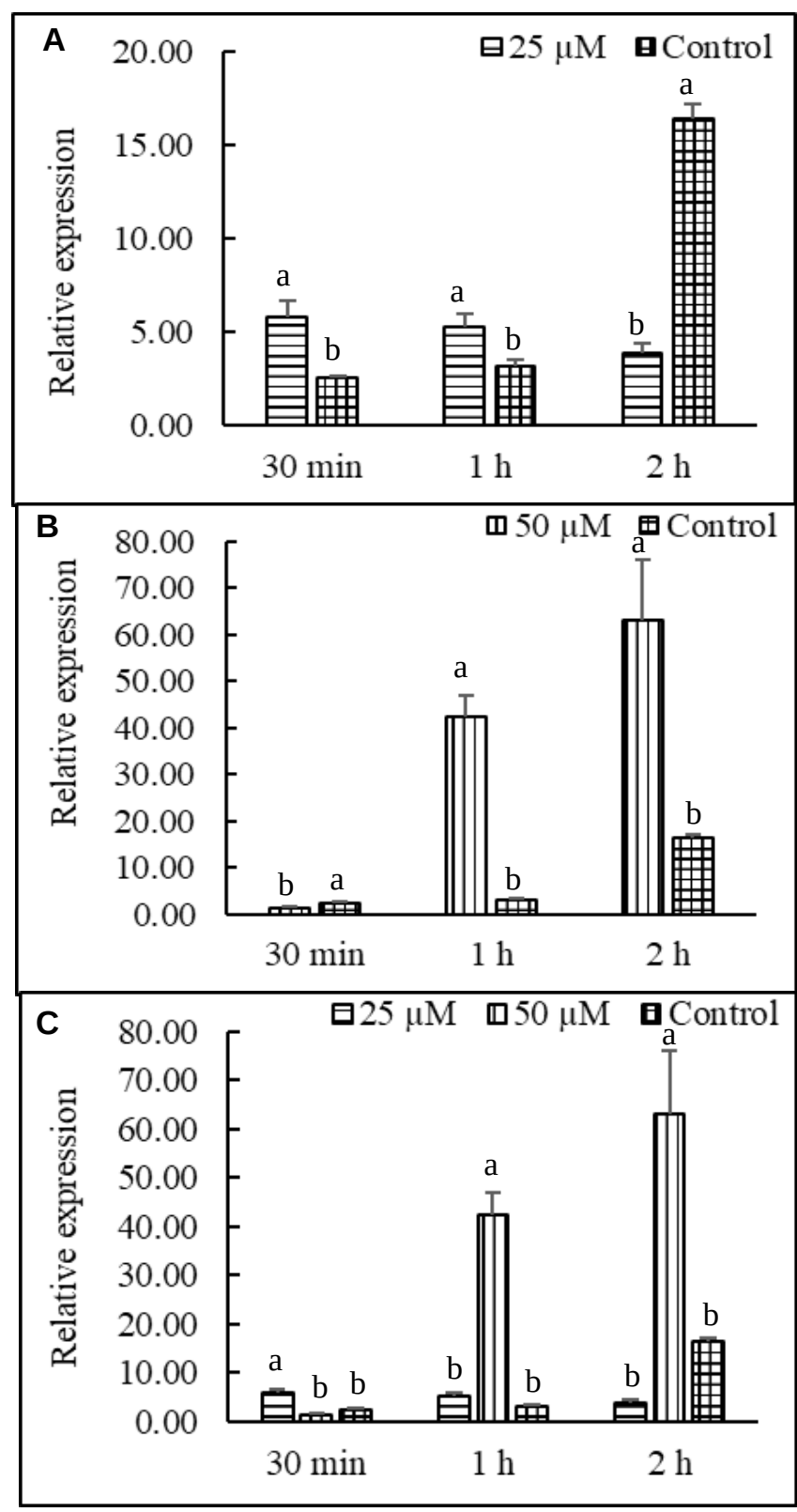

Fig. 3. Relative quantification of AAP-like gene after Alanine addition. A: $25 \mu \mathrm{M}$; B: $50 \mu \mathrm{M}$; C: $25 \mu \mathrm{M}, 50 \mu \mathrm{M}$ and control using IDE as internal control. Each column is the average of the three independent measure \pm SD. Small alphabets notation on each error bars indicated significant differences and same alphabet notation indicated no significant differences at the $5 \%$ level of significance in between treatment and controlof a particular incubation time. AAP-like- amino acid permease-like gene; IDE- Insulin degrading enzyme.

Based on the great significance of $A A P$ gene in the agriculture, localization along with functional characterization has been done (15). Very recently it has been cloned and its protein is structurally characterized in Phaseolus vulgaris (36). Additionally, $A A P 6$ has also been explored to play a key role in export of nitrogen and its fixation in nodule in pea (37). Therefore, it's imperative to check on AAP transporters present naturally in other vital plants.

We addressed question in our study whether, plants can obtain amino acids through AAP transporters in the presence of amino acids at or close to field allied concentrations for roots. The high relative expression of $A A P$-like gene in $50 \mu \mathrm{M}$ of alanine, glycine and proline but at $1 \mathrm{hr}$ and $2 \mathrm{hr}$ for

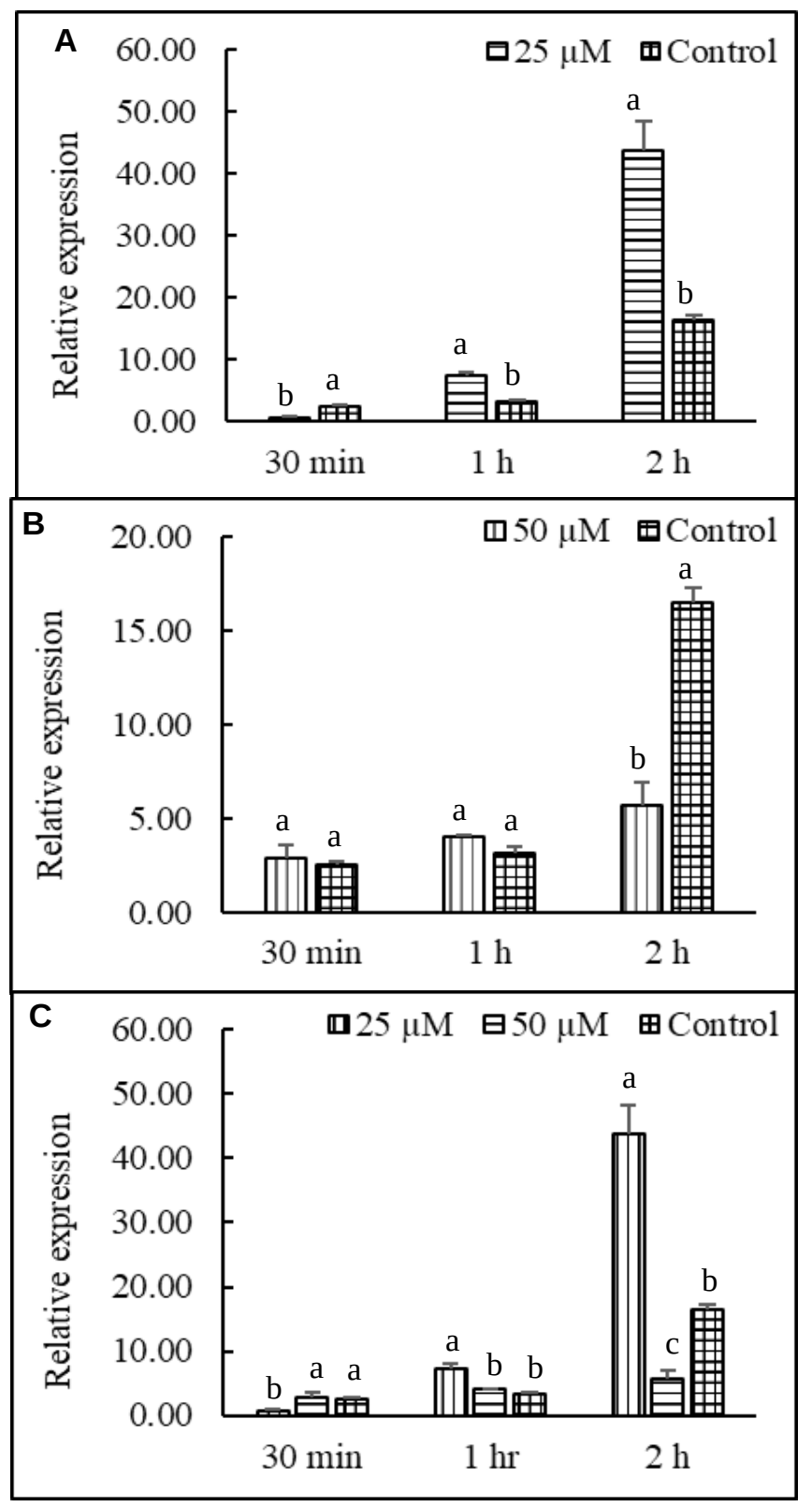

Fig. 4. Relative quantification of AAP-like gene after Proline addition. A: $25 \mu \mathrm{M}$; B: $50 \mu \mathrm{M}$; C: Comparison between $25 \mu \mathrm{M}, 50 \mu \mathrm{M}$ and control using IDE as internal control.Each column is the average of the three independent measure \pm SD. Small alphabets notation on each error bars indicated significant differences and same alphabet notation indicated no significant differences at the $5 \%$ level of significance in between treatment and control of a particular incubation time. AAP-like- amino acid permease-like gene; IDE- Insulin degrading enzyme.

alanine; $2 \mathrm{hr}$ for glycine and $30 \mathrm{~min}$ for proline (Fig. 1). From this observation it is obvious to say, more the concentration of amino acid, more will be the expression of AAP-like gene. However, 7.68 fold $A A P$ like gene expression in $25 \mu \mathrm{M}$ proline then in $50 \mu \mathrm{M}$ of proline indicates that the AAP-like gene expression is dependent on the presence of specific amino acid. Another important observation is that the AAP-like gene expression gradually increases as time passes from $30 \mathrm{~min}$ to $2 \mathrm{hr}$, regardless of the concentrations of amino acids (Fig. 2-4).

\section{Conclusion}

This is the first study showing the involvement of $A A P$ transporter in acquiring amino acids, glycine, 
alanine and proline and establish a dose dependent relationship with the expression of $A A P$ at field allied concentrations for root. Additionally, the necessity of more information on the twinning of uptake, stimulus, metabolic pathways, soil properties and plant growth in the presence of other amino acids along with organic nitrogenous compounds are required. Based on this knowledge, we can stop the wasting of excess nitrogen fertilizer applied in the field that will halt eutrophication along with leaching through roots in the surrounding environment. The identification and breeding of plants showing high ability in absorbing nitrogen could also bring a breakthrough in agricultural system leading to low fertilizer usage in the field.

\section{Acknowledgement}

Authors are grateful to the Department of Biotechnology. Visva-Bharati for financial support.

\section{Authors contributions}

$\mathrm{NP}, \mathrm{BC}$ and JB designed the research. NP and BC carried out the experiment. $\mathrm{NP}, \mathrm{BC}$ and JB contributed manuscript preparation and finalized the manuscript.

\section{Conflict of interest}

The authors declare no conflict of interest.

\section{References}

1. Williams LE, Miller AJ. Transporters responsible for the uptake and partitioning of nitrogenous solutes. Annu Rev Plant Physiol Plant Mol Biol. 2001;52:659-88. https://doi.org/10.1146/annurev.arplant.52.1.659

2. Tegeder M, Rentsch D. Uptake and partitioning of amino acids and peptides. Mol Plant. 2010;3(6):997-1011. https://doi.org/ $10.1093 / \mathrm{mp} / \mathrm{ssq} 047$

3. Rahmoune B, Zerrouk IZ, Bouzaa S, Morsli A, Khelifi-Slaoui M, Ludwig-Müller J, Khelifi L. Amino acids profiling in Datura stramonium and study of their variations after inoculation with plant growth promoting Rhizobacteria. Biologia. 2019;74:1373-83. https://doi.org/10.2478/s11756-019-00287-y

4. Tegeder M, Weber APM. Metabolite transporters in control of primary plant metabolism. In: Plaxton WC, McManus MT, editors. Control of Primary Metabolism in Plants. 2006;85-120. https://doi.org/10.1002/9780470988640.ch4

5. Rentsch D, Schmidt S, Tegeder M. Transporters for uptake and allocation of organic nitrogen compounds in plants. FEBS Letters. 2007;581:2281-89. https://doi.org/10.1016/ j.febslet.2007.04.013

6. Tegeder M. Transporters for amino acids in plant cells: some functions and many unknowns. Curr Opin Plant Biol. 2012;15:315-21. https://doi.org/10.1016/j.pbi.2012.02.001

7. Fischer WN, Kwart M, Hummel S, Frommer WB. Substrate specificity and expression profile of amino acid transporters (AAPs) in Arabidopsis. J Biol Chem. 1995;270(27):16315-20. https://doi.org/10.1074/jbc.270.27.16315

8. Fischer WN, Loo DD, Koch W, Ludewig U, Boorer KJ, Tegeder $\mathrm{M}$, et al. Low and high affinity amino acid $\mathrm{H}^{+-}$-cotransporters for cellular import of neutral and charged amino acids. Plant J.
2002;29(6):717-31.

313X.2002.01248.x

https://doi.org/10.1046/j.1365-

9. Svennerstam H, Ganeteg U, Bellini C, Näsholm T. Root uptake of cationic amino acids by Arabidopsis depends on functional expression of amino acid permease. New Phytol. 2008;180:620 30. https://doi.org/10.1111/j.1469-8137.2008.02589.x

10. Schwacke R, Schneider A, Van Der Graaff E, Fischer K, Catoni E, Desimone M, et al. Aramemnon, a Novel Database for Arabidopsis Integral Membrane Proteins. Plant Physiol. 2003;131(1):16-26. https://doi.org/10.1104/pp.011577

11. Jamtgard S, Näsholm T, Huss-Danell K. Characteristics of amino acid uptake in barley. Plant Soil. 2008;302:221-31. https://doi.org/10.1007/s11104-007-9473-4

12. Svennerstam H, Jämtgard S, Ahmad I, Huss-Danel K, Näsholm T, Ganeteg U. Transporters in Arabidopsis roots mediating uptake of amino acids at naturally occurring concentrations. New Phytol. 2011;191:459-67. https://doi.org/10.1111/j.14698137.2011.03699.x

13. Nithin, C, Patwa N, Thomas A, Bahadur RP, Basak J. Computational prediction of miRNAs and their targets in Phaseolus vulgaris using simple sequence repeat signatures. BMC Plant Biol. 2015;15:1-16. https://doi.org/10.1186/s12870-015-0516-3

14. Patwa N, Nithin C, Bahadur RP, Basak J. Identification and characterization of differentially expressed Phaseolus vulgaris miRNAs and their targets during mungbean yellow mosaic India virus infection reveals new insight into Phaseolus-MYMIV interaction. Genomics. 2019;111:1333-42. https://doi.org/ 10.1016/j.ygeno.2018.09.005

15. Tan Q, Grennan AK, Pélissier HC, Rentsch D, Tegeder M. Characterization and expression of French bean amino acid transporter PvAAP1. Plant Sci. 2008;174:348-56. https://doi.org 10.1016/j.plantsci.2007.12.008

16. Murashige T, Skoog F. A revised medium for rapid growth and bioassays with tobacco tissue cultures. Physiol Plant. 1962;15:473-97.https://doi.org/10.1111/j.1399-054.1962.tb08052.x

17. Artimo P, Jonnalagedda M, Arnold K, Baratin D, Csardi G, de Castro E, et al. ExPASy: SIB bioinformatics resource portal. Nucleic Acids Res, 2012;40(W1):W597-W603. https://doi.org/ 10.1093/nar/gks400

18. Koressaar T, Lepamets M, Kaplinski L, Raime K, Andreson R, Reme M. Primer3_masker: integrating masking of template sequence with primer design software. Bioinformatics. 2018;34(11):1937-38. https://doi.org/10.1093/bioinformatics/ bty036

19. Borges A, Tsai SM, Caldas DGG. Validation of reference genes for RT-qPCR normalization in common bean during biotic and abiotic stresses. Plant Cell Rep 2012;31:827-38. https://doi.org/ 10.1007/s00299-011-1204-x

20. Schmittgen TD, Livak KJ. Analyzing real-time PCR data by the comparative $\mathrm{C}_{\mathrm{T}}$ method. Nat Protoc. 2008;3:1101-08. https:// doi.org/10.1038/nprot.2008.73

21. Jones DL, Owen AG, Farrar JF. Simple method to enable the high resolution determination of total free amino acids in soil solutions and soil extracts. Soil Biol Biochem. 2002;34:1893-02. https://doi.org/10.1016/S0038-0717(02)00203-1

22. Hill PW, Quilliam RS, DeLuca TH, Farrar J, Farrell M, Roberts P, et al. Acquisition and Assimilation of Nitrogen as PeptideBound and D-Enantiomers of Amino Acids by Wheat. PLoS One. 2011;6: e19220. https://doi.org/10.1371/ journal.pone.0019220

23. Raab TK, Lipson DA, Monson RK. Non-mycorrhizal uptake of amino acids by roots of the alpine sedge Kobresia myosuroides: implications for the alpine nitrogen cycle Oecologia.1996;108:488-94. https://doi.org/10.1007/BF00333725

24. Öhlund J. Organic and inorganic nitrogen sources for conifer seedlings: abundance, uptake and growth. Doctoral thesis. Swedish University of Agricultural Sciences. PhD [Dissertation]. Umea: Department of Forest Genetics and Plant Physiology, Swedish University of Agricultural Sciences; 2004. Available from: http://urn.kb.se/resolve?urn=urn:nbn:se:slu:epsilon278 
25. Wright DE. Amino acid uptake by plant roots. Arch Biochem Biophys. 1962;97:174-180. https://doi.org/10.1016/00039861(62)90061-9

26. Schmidt S, Stewart GR. Glycine metabolism by plant roots and its occurrence in Australian plant communities. Aust J Plant Physiol. 1999;26:253-64. https://doi.org/10.1071/PP98116

27. Owen AG, Jones DL. Competition for amino acids between wheat roots and rhizosphere micro-organisms and the role of amino acids in plant $\mathrm{N}$ acquisition. Soil Biol Biochem. 2001;33:651-57. https://doi.org/10.1016/S0038-0717(00)00209-1

28. Soldal T, Nissen P. Multiphasic uptake of amino acids by barley roots. Physiol Plant. 1978;43:181-88. https://doi.org/10.1111/ j.1399-3054.1978.tb02561.x

29. Schobert C, Komor E. Amino-acid-uptake by Ricinus communis roots - characterization and physiological significance. Plant Cell Environ. 1987;10:493-500. https://doi.org/10.1111/j.13653040.1987.tb01827.x

30. Kielland K. Amino acid absorption by arctic plants: Implications for plant nutrition and nitrogen cycling. Ecology. 1994;75(8):2373-83. https://doi.org/10.2307/1940891

31. Nasholm T, Ekblad A, Nordin A, Giesler R, Hogberg M, Hogberg P. Boreal forest plants take up organic nitrogen. Nature. 1998;392:914-16. https://doi.org/10.1038/31921
32. Harrison J, Brugiere N, Phillipson B, Ferrario-Mery S, Becker T, Limami A, Hirel B. Manipulating the pathway of ammonia assimilation though genetic engineering and breeding: consequences to plant physiology and plant development. Plant Soil. 2000;221:81-93. https://doi.org/10.1023/A:1004715720043

33. Persson J, Nasholm T. Regulation of amino acid uptake in conifers by exogenous and endogenous nitrogen. Planta. 2002;215:639-44. https://doi.org/10.1007/s00425-002-0786-5

34. Gioseffi E, Neergaard Ade, Schjoerring JK. Interactions between uptake of amino acids and inorganic nitrogen in wheat plants. Biogeosciences. 2012;9:1509-18. https://doi.org/10.5194/ bg-9-1509-2012

35. Lipson DA, Nasholm T. The unexpected versatility of plants: organic nitrogen use and availability in terrestrial ecosystems. Oecologia. 2001;128:305-16. https://doi.org/10.1007/ s004420100693

36. Chakraborty N, Besra A, Basak J. Molecular Cloning of an Amino Acid Permease Gene and Structural Characterization of the Protein in Common Bean (Phaseolus vulgaris L.). Mol Biotechnol. 2020;62. https://doi.org/10.1007/s12033-020-00240-4

37. Garneau MG, Tan Q, Tegeder M. Function of pea amino acid permease AAP6 in nodule nitrogen metabolism and export, and plant nutrition. J Exp Bot. 2018; 69(21):5205-19. https:// doi.org/10.1093/jxb/ery289 